\begin{tabular}{c} 
Volume and Issues Obtainable at Center for Sustainability Research and Consultancy \\
Journal of Accounting and Finance in Emerging Economies \\
ISSN: $2519-0318$ ISSN (E) 2518-8488 \\
Volume 6: Issue 4 December 2020 \\
CSRᄃ \\
Journal homepage: $\underline{\text { www.publishing.globalcsrc.org/jafee }}$ \\
\hline
\end{tabular}

\title{
Have Moroccan National Accounting Council and Academic Researchers Overestimated the Benefits of Adopting IFRS?
}

\author{
${ }^{1}$ Khalifa Ahsina \\ ${ }^{1}$ Associate Professor, Faculty of Economics, Ibn Zohr University, Ait Melloul, Morocco, \\ k.ahsina@uiz.ac.ma
}

\begin{tabular}{l}
\hline ARTICLE DETAILS \\
\hline History \\
Revised format: November \\
2020 \\
Available Online: December \\
2020
\end{tabular}

Keywords

Accounting, IFRS,

Value relevance, Morocco,

Academic researchers

JEL Classification

M40, M41

\begin{abstract}
Purpose: In Morocco, the opening to IFRS standards was made in 2007 by the constraint of financial institutions to publish their financial statements according to IFRS standards. The aim of implementing IFRS accounting standards is to increase the relevance of accounting and its usefulness for stakeholders. However, the adoption of these standards often emanates from the requirements of international financial institutions which prescribe IFRS standards to be in harmony with those of developed countries. Following on from the question asked by Christensen in 2012, have the Moroccan National Accounting Council and academics researchers overestimated the benefits of adopting IFRS? Design/Methodology/Approach: Based on the price and return model developed by Amir et al (1993), our article aims to measure the effect of the implementation of IFRS on the relevance of Moroccan accounting. Findings: The results show that the adoption of IFRS does not bring value relevance compared to national accounting standards. The coefficients of determinations are low. Implications/Originality/Value: This study presents a scientific and managerial contribution on several levels. Indeed, for financial managers, accountants, and shareholders of listed companies, the implementation of IFRS does not have a significant impact on the quality of accounting figures. That being said, national accounts are as relevant in terms of quality as IFRS. It may be necessary to invest in other projects such as the modernization of accounting information systems to better manage financial reporting.
\end{abstract}

(C) 2020 Center for Sustainability Research and Consultancy Pakistan under a Creative Commons Attribution-NonCommercial-ShareAlike

Corresponding author's email address: k.ahsina@uiz.ac.ma

Recommended citation: Ahsina, K. (2020). Have Moroccan national accounting council and academic researchers overestimated the benefits of adopting IFRS?. Journal of Accounting and Finance in Emerging Economies, 6(4), 1173-1179

\section{Introduction}

In the absence of an official chart of accounts in Morocco before 1992 and due to the poverty of economic and financial information generated by company accounts and its inadequacy to the economic 
and social realities of the country, an "Accounting National Committee" was created in 1983.

This accounting framework, inspired by the 4th and 7th European directives, constituted a means of linking up with the movement of international accounting standardization and in particular in Europe Also, in 2002, recommendations for improving the adopted accounting framework were formulated by experts from the World Bank as part of a report to assess compliance with standards and codes, particularly in the area of auditing and accounting. . The report considers that the Moroccan accounting framework does not allow to reflect the real economic situation of companies.

As part of the process of international and European accounting standardization, the National Accounting Council has chosen to converge Moroccan accounting standards to IFRS standards.

Or, thirteen years after their mandatory adoption in Morocco, IFRS (International Financial Reporting Standards) continue to feed the debates. The implementation of IFRS accounting standards aims to increase the relevance of accounting and its usefulness for stakeholders. However, the adoption of these standards often emanates from the requirements of international financial institutions which prescribe IFRS standards to be in harmony with those of developed countries. Following on from the question asked by Christensen in 2012, have the Moroccan National Accounting Council and academics researchers overestimated the benefits of adopting IFRS?

Much research has been carried out in developed countries to answer the question of the superiority of IFRS over national standards, but the answers remain ambiguous. On the other hand, Moroccan research is rare, which has focused on the question of research into the superiority of IFRS standards, hence the interest of this research. The plan of the article is as follows: the literature on the value relevance of IFRS standards will be proposed in the first section, then we will present the research methodology in the second section 2. In the third section, the results will be presented and we will discuss them. The results will be presented in the last section.

\subsection{Value Relevance of IFRS: A Controversial Debate}

This literature review attempts to highlight studies on the value relevance of IFRS about national accounting standards.Callao and Jarne (2007) as well as Barth and al. (2008), showed that the implementation of IFRS had the effect of improving financial information.

As with the limited empirical research on developing countries, according to Wallace (1990), empirical work on the relevance of international accounting standards for these nations is relatively minimal. Similarly, in some African countries, the results of the work of Chamisa (2000, Zimbabwe) indicate that the value of banks' equity and earnings are relatively more relevant under IFRS than under local accounting standards. Subramanyam (2007), unlike Barth et al (2008), found that the relevance of the value of German accounting standards is higher than that of IFRS. Likewise, Schiebel (2007) concludes with the same results of the superiority of German standards compared to IFRS standards.

However, according to Bessieux and Walliset, (2017), to simplify structures and reduce costs, many companies in Europe have decided to abandon the IFRS accounting standards used and switch to national standards. 
Table 1. Literature review on the adoption of IFRS

\begin{tabular}{|c|c|c|c|}
\hline Authors & Sample & $\begin{array}{l}\text { Research } \\
\text { methodology }\end{array}$ & Results \\
\hline $\begin{array}{l}\text { Bessieux and } \\
\text { Walliset. (2017) }\end{array}$ & $\begin{array}{l}4 \text { French companies listed } \\
\text { on Alternext }\end{array}$ & $\begin{array}{l}\text { Semi-structured } \\
\text { interviews }\end{array}$ & $\begin{array}{l}\text { IFRS, constantly evolving, induce significant training } \\
\text { costs. The complexity of standards is also seen as } \\
\text { crippling, causing "endless discussions". The four } \\
\text { companies even go so far as to consider them } \\
\text { unnecessary, without much interest }\end{array}$ \\
\hline Barth, et al (2008) & $\begin{array}{l}21 \quad \text { countries, } 1896 \\
\text { Companies }\end{array}$ & $\begin{array}{l}\text { Multiple } \\
\text { regression }\end{array}$ & $\begin{array}{l}\text { Improvement of the accounting quality of companies } \\
\text { applying IFRS standards. }\end{array}$ \\
\hline $\begin{array}{lll}\text { Callao et Jarne } \\
2007\end{array}$ & $\begin{array}{l}11 \text { European countries } \\
\text { and } 1408 \text { companies }\end{array}$ & $\begin{array}{l}\text { Multiple } \\
\text { regression }\end{array}$ & $\begin{array}{l}\text { The results obtained show an improvement in } \\
\text { financial information's }\end{array}$ \\
\hline Chamisa (2000) & \begin{tabular}{|ll}
$\begin{array}{l}\text { Zimbabwe, } \\
\text { companies }\end{array}$ & 40 listed \\
\end{tabular} & A case study. & $\begin{array}{l}\text { the implementation of these standards has improved } \\
\text { the accounting practices of listed companies }\end{array}$ \\
\hline Vafaei (2010) & $\begin{array}{l}325 \text { listed companies from } \\
\text { six countries }\end{array}$ & $\begin{array}{l}\text { explanatory } \\
\text { study }\end{array}$ & $\begin{array}{l}\text { The authors did not find any differences between } \\
\text { IFRS and accounting standards. }\end{array}$ \\
\hline $\begin{array}{l}\text { Niskanen and al } \\
(2000)\end{array}$ & Finland, 97 companies & $\begin{array}{l}\text { Multiple } \\
\text { regression } \\
\text { (Earnings } \\
\text { model) } \\
\end{array}$ & $\begin{array}{l}\text { The authors did not find any differences between } \\
\text { IFRS and Finnish accounting standards. }\end{array}$ \\
\hline $\begin{array}{l}\text { Hung and } \\
\text { Subramanyam } \\
(2007)\end{array}$ & $\begin{array}{l}\text { Germany, } 80 \text { industrial } \\
\text { companies }\end{array}$ & $\begin{array}{l}\text { Multiple } \\
\text { regression }\end{array}$ & National accounting is more relevant than IFRS \\
\hline $\begin{array}{l}\text { Lopes C and al } \\
(2010)\end{array}$ & $\begin{array}{l}5 \text { countries of the } \\
\text { European Union and } 2 \\
\text { countries not belonging to } \\
\text { the European Union }\end{array}$ & $\begin{array}{l}\text { Multiple } \\
\text { regression }\end{array}$ & $\begin{array}{l}\text { For companies in the European Union, IFRS hurts the } \\
\text { quality of accounting. For others, the adoption of } \\
\text { IFRS improve the quality of accounting standards }\end{array}$ \\
\hline
\end{tabular}

After this literature on the value relevance of IFRS compared to national accounting standards, we will now focus on the case of Moroccan companies. In this research on the Moroccan context, we will apply the model of Amir and al to assess the relevance of IFRS compared to the Moroccan accounting standard. Therefore, from this literature review we make the following hypotheses:

Hypothesis 1: the implementation of IFRS increases the quality of information on net income, Hypothesis 2: The adoption of IFRS improves the informational content of equity.

\section{Research Methodology}

To test the value relevance of IFRS, in the Moroccan context, we are studying the association between market profitability and net income according to Moroccan standards on the one hand and according to IFRS standards on the other.

After a presentation of the models, we will describe our sample.

\subsection{Price-Based Modeling}

The price-based model takes the stock market price as the explained variable and the earnings and book value of equity as the explanatory value. Thus, the value of a business is a linear function of its profits and equity.

$$
\mathrm{P}_{\mathrm{i}, \mathrm{t}}=\beta_{0}+\beta_{1} \mathrm{BPA}_{\mathrm{i}, \mathrm{t}}{ }^{\mathrm{M}}+\beta_{2} \mathrm{BPA}_{\mathrm{i}, \mathrm{t}}{ }^{\mathrm{DIF}}+\beta_{3} \mathrm{CPPAj}_{\mathrm{i}, \mathrm{t}}{ }^{\mathrm{M}}+\beta_{4} \mathrm{CPPAj}_{\mathrm{i}, \mathrm{t}}{ }^{\mathrm{DIF}}+\boldsymbol{\varepsilon}_{\mathrm{i}, \mathrm{t}}
$$

We therefore have, for each company $i$ and according to year $t$ :

$\mathrm{Pi}, \mathrm{t}$ : the stock price

$\mathrm{BPA}_{\mathrm{i}, \mathrm{t}} \mathrm{M}$, earnings per share under Moroccan accounting

BPA $_{i, t}$ DIF : the difference in earnings per share between IFRS and the Moroccan accounting $\mathrm{CPPA}_{\mathrm{ji}, \mathrm{t}} \mathrm{M}$ : equity per share adjusted to earnings per share under Moroccan accounting CPPA $_{i, t}$ DIF, the difference in adjusted equity per share between IFRS and the Moroccan accounting. 
The adoption of IFRS is relevant for these companies, if the coefficients $\beta_{2}$ and $\beta_{4}$ are significantly different from 0.

\subsection{Modeling Based on Return}

According to this model, stock market profitability can be explained in a multivariate model which groups together net income and its variation, normalized by the price at the start of the period. Thus, the test of the relevance of net income according to the accounting standards applied results in the study of the association between market profitability and net income and its variation.

Thus, the empirical version of this model makes it possible to express the return as a function of the net income and the change in the net income of companies as follows:

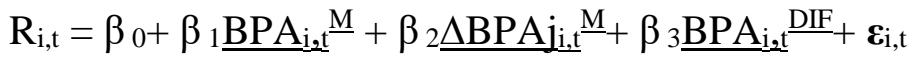

$$
\begin{aligned}
& \mathrm{Pi}, \mathrm{t}-1 \quad \mathrm{Pi}, \mathrm{t}-1 \quad \mathrm{Pi}, \mathrm{t}-1
\end{aligned}
$$

We therefore have, for each company $i$ and according to year $t$ :

$\mathrm{Ri}, \mathrm{t}$ : the stock market performance,

BPAji,t : earnings per share in Moroccan accounting,

$\triangle B P A j i, t$ : the change in earnings per share under Moroccan,

$\mathrm{BPA}_{\mathrm{i}_{2} \mathrm{~L}} \mathrm{DIF}$ : the difference in earnings per share between Ifrs and Moroccan accounting.

If the coefficient $\beta_{3}$ is statistically different from 0 , then the IFRS is more relevant than the Moroccan accounting.

\subsection{Sample Description}

In the case of Morocco, the Moroccan accounting framework has remained frozen in the face of the changes induced by IFRS standards. The process of convergence of accounting standards with international standards (IFRS) has so far been limited to groups in the financial sector and listed companies. Our sample is made up of Moroccan companies listed on the Casablanca financial market and which have communicated for their transitional financial year their accounts according to Moroccan accounting standards and IFRS.

For the sake of consistency of conclusions, we limited ourselves to listed non-financial consolidating companies, therefore excluding credit institutions and the like. Our initial sample consisted of the 12 non-financial groups listed on the Casablanca financial market at the end of 2013. The rest of the fifty or so listed companies are non-consolidating companies. The accounting data for the year of the first application of IFRS were obtained either from the Casablanca financial market database, or from that of the Financial Markets Authority, or at the direct request of the financial services of the companies concerned.

The data compared in NCM could not be obtained for 3 groups in our sample (Afriquia Gaz, Maghreb Oxygène and Centrale laitière). For the other groups selected, it is important to point out that due to the optional nature of the application of IFRS standards, different dates have been retained for the analysis of the comparative financial statements. However, 2007 was the one that saw the greatest acceleration in the implementation of IFRS, since it was from this year that the Financial Markets Authority intensified its efforts to control the accounting publications of Moroccan companies and promote adoption of IFRS.

Table 2 - Data

\begin{tabular}{|l|c|}
\hline Companies listed on the Casablanca financial market & 75 \\
\hline Financial and insurance companies & -19 \\
\hline Non-consolidating companies & -44 \\
\hline
\end{tabular}




\begin{tabular}{|l|c|} 
Companies with incomplete data & -3 \\
\hline Companies in the sample & 9 \\
\hline
\end{tabular}

According to the literature, we eliminated companies which have a particular accounting from our sample to obtain homogeneous companies.

\section{Empirical Results}

We will first present the results of the modeling based on prices, then in a second step that on profitability, the objective is to analyze the value relevance of the adoption of IFRS on equity and profits.

\subsection{The Value Relevance through Pricing Models}

In this section, we present the results of the value relevance of IFRS and Moroccan accounting through models based on prices and profits.

Table 3. Price-based modeling

\begin{tabular}{|c|c|c|c|c|c|c|}
\hline & \multicolumn{2}{|c|}{$\begin{array}{c}\text { Model 1 } \\
\text { (Moroccan Accounting } \\
\text { Standards) }\end{array}$} & \multicolumn{2}{|c|}{ Model 2 -IFRS } & \multicolumn{2}{|c|}{ Model 3} \\
\hline & $\begin{array}{l}\text { Unstandardized } \\
\text { coefficients }\end{array}$ & Sig. & $\begin{array}{l}\text { Unstandardized } \\
\text { coefficients }\end{array}$ & Sig. & $\begin{array}{l}\text { Unstandardized } \\
\text { coefficients }\end{array}$ & Sig. \\
\hline Constant & 957,28 & 0,31 & 589,589 & 0,34 & 1091,613 & 0,419 \\
\hline $\mathrm{BPA}_{\mathrm{i}, \mathrm{t}}{ }^{\mathrm{M}}$ & 9,81 & 0,32 & & & 9,323 & 0,452 \\
\hline $\mathrm{CPPA}_{\mathrm{ji}, \mathrm{t}}{ }^{\mathrm{M}}$ & $-12,97$ & 0,68 & & & $-26,124$ & 0,711 \\
\hline $\mathrm{BPA}_{\mathrm{i}, \mathrm{t}}{ }^{\mathrm{IFRS}}$ & & & 11,521 & 0,2 & & \\
\hline $\mathrm{CPPA}_{\mathrm{i}, \mathrm{t}}{ }^{\mathrm{IFRS}}$ & & & $-0,563$ & 0,86 & & \\
\hline $\mathrm{BPA}_{\mathrm{i}, \mathrm{t}} \mathrm{DIF}$ & & & & & 1,411 & 0,838 \\
\hline $\mathrm{CPPA}_{\mathrm{i}, \mathrm{t}} \mathrm{DIF}$ & & & & & $-0,413$ & 0,823 \\
\hline $\mathrm{R}^{2}$ & \multicolumn{2}{|l|}{$28,70 \%$} & \multicolumn{2}{|l|}{$26,00 \%$} & \multicolumn{2}{|c|}{$29,77 \%$} \\
\hline
\end{tabular}

We observe that in Model 1 which is based on Moroccan accounting data, that indeed there is a positive association between stock price and profits and a negative association with equity. But these coefficients are not statistically significant.

We also observe that there is no difference in terms of quality between Moroccan accounting and IFRS. Adding other variables to Model 3, results in a small improvement in the coefficient of determination $\mathrm{R}^{2}$.

\subsection{Modeling Based on Stock Return}

In the latter model, in accordance with the literature, earnings per share are weakly associated with stock market performance. We also found that the relationship between profit variation and stock market performance is insignificant. In line with the literature, these results confirm the alternative hypothesis according to which there is no significant difference between Moroccan accounting and IFRS compared to accounting quality.

Table4. Modeling Results Based on Stock Returns

\begin{tabular}{|l|c|c|c|c|}
\hline & \multicolumn{2}{|c|}{ Model 4 } & \multicolumn{2}{c|}{ Model 5 } \\
\hline & $\begin{array}{c}\text { Unstandardized } \\
\text { coefficients }\end{array}$ & Sig. & $\begin{array}{c}\text { Unstandardized } \\
\text { coefficients }\end{array}$ & Sig. \\
\hline (Constant) & 0,01 & 0,96 & 0,006 & 0,979 \\
\hline
\end{tabular}




\begin{tabular}{|l|c|c|c|c|}
\hline$\frac{\mathrm{BPAi}, \mathrm{PM}}{\mathrm{Pi}, \mathrm{t}-1}$ & 0,02 & 0,51 & 0,002 & 0,569 \\
\hline$\frac{\Delta \mathrm{BPAi}, \mathrm{tM}}{\mathrm{Pi}, \mathrm{t}-1}$ & 0,047 & 0,69 & 0,081 & 0,787 \\
\hline$\frac{\mathrm{BPAi}, \mathrm{tDIF}}{\mathrm{Pi}, \mathrm{t}-1}$ & & & $-0,006$ & 0,9 \\
\hline \multicolumn{1}{|c|}{$\mathrm{R}^{2}$} & $8,77 \%$ & & $9,09 \%$ \\
\hline
\end{tabular}

\section{Conclusion and Discussion}

This article aimed to find out whether the adoption of IFRS will provide more relevant information compared to the Moroccan accounting of listed companies. We selected a sample of 9 companies listed on the Moroccan financial market and we used the model of Amir and al, in our research methodology.According to Niskanen, and al as well as Vafaei, the results of this research showed the low-value relevance of IFRS compared to Moroccan accounting standards. However, the results obtained cannot overshadow the gaps associated with it.

In the first order, the small size of the sample. To resolve this problem, it is advisable to widen the study sample by integrating commercial companies or service providers while considering sector specificities. In the second-order, the use of multiple regressions imposes constraints on compliance with the assumptions of multi normality of the explanatory variables, which influences the quality of the model. The use of PLS regression is an interesting line of research because it tolerates such conditions. However, this study presents a scientific and managerial contribution on several levels. Indeed, for financial managers, accountants, and shareholders of listed companies, the implementation of IFRS does not have a significant impact on the quality of accounting figures. That being said, national accounts are as relevant in terms of quality as IFRS. It may be necessary to invest in other projects such as the modernization of accounting information systems to better manage financial reporting.

\section{References}

Amir, E., Harris, T., \& Venuti, E. (1993). A Comparison of the Value-Relevance of US versus non-US GAAP Accounting Measures Using Form 20-F Reconciliations. Journal of Accounting Research, $31,230-264$.

Barth B and al (2008). International Accounting Standards and Accounting Quality. Journal of Accounting Research, 2008, vol. 46, issue 3, pages 467-498

Bessieux-Ollier, C. \& Walliser, É. (2017). La renonciation au référentiel comptable international : Une contribution au débat controversé sur les bienfaits systématiques des IFRS. Recherches en Sciences de Gestion, 118(1), 45-64.

Chamisa, E. E. (2000). The Relevance and observance of IASC standards in developing countries and the particular case of Zimbabwe. The International Journal of Accounting, 35, 267-286

Callao S and al (2007). Adoption of IFRS in Spain: Effect on the comparability and relevance of financial reporting. Journal of International Accounting, Auditing, and Taxation. 16 (2007) 148178.

Christensen H., « Why do firms rarely adopt IFRS voluntarily? Academic find significant benefits and the cost appear to be low », Review of Accounting Studies, Vol. 17, 2012 p. 518-525.

Hung, M., Subramanyam, KR. (2007). Financial Statement Effects of the Adoption of International Accounting Standards: The Case of Germany. Review of Accounting Studies 12(4), p. 623-657.

Niskanen, J., Kinnunen, J. ve Kasanen, E. (2000) "The Value Relevance of IAS Reconciliation: Empirical Evidence from Finland" Journal of Accounting and Public Policy, 19(2):119-37

Lopes $C$ et ali (2010). Impact of IFRS adoption on accounting quality in European firms. Journal of Modern Accounting and Auditing. Vol.6, No.9

Schiebel, Alexander, Value Relevance of German Gaap and IFRS Consolidated Financial Reporting: An Empirical Analysis on the Frankfurt Stock Exchange (July 10, 2007). 
Vafaei, A (2010): "The Value Relevance of IFRS Adoption: Cross Country Comparison Based on Harmonization Histories, Intellectual Capital Disclosures and the Global Financial Crisis." A Thesis Submitted in Award of the Degree of philosophy (Ph.D.), School of Accounting, College of Business, RMIT University.

Wallace, R. (1990). Accounting in developing countries: A review of the literature. Research in Third World Accounting, 1, 1-22. 